\title{
The Arabidopsis cytosolic ribosomal proteome: from form to function
}

\author{
Adam J. Carroll* \\ Australian Research Council Centre of Excellence in Plant Energy Biology, Australian National University, Canberra, ACT, Australia
}

Edited by:

Harvey Millar, The University of

Western Australia, Australia

\section{Reviewed by:}

Peta Bonham-Smith, University of

Saskatchewan, Canada

Kenichi Yamaguchi, Nagasaki

University, Japan

*Correspondence:

Adam J. Carroll, Australian Research

Council Centre of Excellence in Plant

Energy Biology, Australian National

University, ACT 0200, Canberra,

Australia.

e-mail: adam.carrol/@anu.edu.au
The cytosolic ribosomal proteome of Arabidopsis thaliana has been studied intensively by a range of proteomics approaches and is now one of the most well characterized eukaryotic ribosomal proteomes. Plant cytosolic ribosomes are distinguished from other eukaryotic ribosomes by unique proteins, unique post-translational modifications and an abundance of ribosomal proteins for which multiple divergent paralogs are expressed and incorporated. Study of the $A$. thaliana ribosome has now progressed well beyond a simple cataloging of protein parts and is focused strongly on elucidating the functions of specific ribosomal proteins, their paralogous isoforms and covalent modifications. This review summarises current knowledge concerning the Arabidopsis cytosolic ribosomal proteome and highlights potentially fruitful areas of future research in this fast moving and important area.

Keywords: Arabidopsis, sub-cellular proteomics, proteomics, ribosomes, cytosolic ribosomes, plants, translation, $80 S$ ribosomes

\section{RIBOSOMES - A FUNDAMENTALLY IMPORTANT TARGET FOR BASIC AND APPLIED SCIENCE}

Ribosomes - the ribonucleoprotein complexes responsible for catalyzing translation - the mRNA-guided synthesis of proteins from aminoacyl-tRNA, GTP and ATP substrates - have fascinated biologists since their Nobel Prize-winning discovery by George E. Palade in 1955 (Zorca and Zorca, 2011). Understanding how ribosomes are made by cells (ribosome biogenesis and structure), how they work (ribosome molecular mechanics) and how they are controlled through transcriptional, translational, and post-translational mechanisms is of fundamental importance for several reasons. The most obvious reason relates to the fundamental role of ribosomes in the generation of proteomes. Like DNA replication and transcription, translation is a basic requirement for life and an integral component of the Central Dogma of molecular biology.

Understanding the molecular mechanics of different ribosomes will increase our capacity to: (1) design bioactive agents to alter their function (Kannan et al., 2012) and (2) rationally engineer them to modify their performance (Piekna-Przybylska et al., 2008; Santoro et al., 2009) or even provide them with completely new functions - e.g., the residue-specific incorporation of unnatural amino acids into designer polypeptides with novel research and industrial applications (Bain et al., 1992; Benner, 1994; Taira et al., 2005; Neumann et al., 2010; Neumann, 2012). Custom-engineered ribosomes have even been used to create synthetic Boolean information processing networks that control gene expression according to rationally designed logic (Rackham and Chin, 2005, 2006). Despite these numerous examples illustrating the power of ribosome engineering in non-plant species, there are, to the author's knowledge, no published examples of applied ribosome engineering in plants. It seems inevitable that powerful applications of plant ribosome engineering will emerge in time.
Another reason for the fundamental importance of ribosome research relates to chemical and energy resource usage. In rapidly dividing yeast cells, up to at least $60 \%$ of transcriptional activity is devoted to ribosome biogenesis alone, consuming vast amounts of nitrogen $(\mathrm{N})$, phosphorous $(\mathrm{P})$, and energy while translation itself represents a further major demand on $\mathrm{N}$ and energy reserves (Warner, 1999; Piques et al., 2009). Understanding the mechanisms controlling ribosome biogenesis and translation in plants could therefore have profound implications for the management, engineering, and utilization of the enormous chemical energy fluxes in natural and agricultural ecosystems.

\section{EUKARYOTIC RIBOSOMES - MORE COMPLEX MACHINES TO BUILD MORE COMPLEX ORGANISMS}

The gross structure of ribosomes is essentially the same between prokaryotes and eukaryotes in that they are both comprised of ribosomal RNAs (rRNAs) and proteins (r-proteins) in large and small subunits. However, the ribosomes of eukaryotes exhibit greater structural complexity, reflecting the greater complexity of molecular mechanics observed in eukaryotic translation (Kapp and Lorsch, 2004). In eukaryotes, nuclear-encoded proteins (i.e., the vast majority of proteins) are synthesized on $80 \mathrm{~S}$ cytosolic ribosomes which are distinguished from the 70S prokaryotic-type ribosomes of bacteria, mitochondria, and plastids by their larger size and higher number of proteins $(\sim 80$ versus $\sim 54)$. Each $80 S$ eukaryotic ribosome is comprised of a large 60S subunit (50S in prokaryotic ribosomes) containing three rRNA molecules (5S, $5.8 \mathrm{~S}$, and a $23 \mathrm{~S}$-like rRNA ranging between $25 \mathrm{~S}$ and $28 \mathrm{~S}$ in plants) and up to 47 different r-proteins and a small $40 \mathrm{~S}$ subunit (30S in prokaryotic ribosomes) containing a single $18 \mathrm{~S}$ rRNA and up to 33 different r-proteins (Wilson and Doudna Cate, 2012).

The precise reasons for all the specific differences between prokaryotic and eukaryotic translation machineries and processes remain largely unknown. However, it seems likely that the higher 
complexity of eukaryotic translation evolved in response to the following needs which, intuitively, seem likely to be characteristic of eukaryotic organisms: (1) to translate with a greater priority toward fidelity and control over speed of ribosome biogenesis; (2) to efficiently and accurately translate mRNAs having (and encoding proteins having) a wider range of primary and secondary structures; (3) to have greater control over the relative rates of translation of specific mRNAs; (4) to have a greater capacity for spatiotemporal ribosome heterogeneity in order to tailor the translation process for different subcellular locations, cell types, and developmental stages (Giavalisco et al., 2005; Komili et al., 2007; Sugihara et al., 2010; Xue and Barna, 2012).

Among eukaryotes, the cytosolic ribosomes of yeast ( $\mathrm{Sac}$ charomyces cerevisiae), rat (Rattus norvegicus), human (Homo sapiens), and Arabidopsis (Arabidopsis thaliana) have been the most extensively characterized. Primarily through the extensive rprotein sequencing and gene cloning efforts of Wool et al. (1995), rat liver ribosomes were the first eukaryotic ribosomes for which a presumed complete list of r-proteins became available and has since served as a useful model for $r$-protein nomenclature in yeast (Mager et al., 1997) and plants (Barakat et al., 2001) although some inconsistencies do still exist between the r-protein nomenclatures of yeast and other eukaryotes. Efforts to characterize the cytosolic ribosomes of other eukaryote lineages have since revealed that all 79 of the r-protein families present in mammalian ribosomes are also represented in the ribosomes of yeast and plants (Wilson and Doudna Cate, 2012) although an additional plant-specific rprotein family known as acidic stalk protein $\mathrm{P} 3$ has been identified in the ribosomes of plants (Szick et al., 1998; Barakat et al., 2001; Chang et al., 2005; Carroll et al., 2008). This deep conservation of the protein composition of eukaryotic ribosomes suggests that the archetypal eukaryotic ribosome evolved very early in eukaryote evolution and that all of the r-protein families are important for ribosome function. That said, considerable primary sequence divergence has occurred between r-protein orthologs of different eukaryote lineages (Wool et al., 1995) and between r-protein paralogs within individual species that have emerged through gene duplication events during eukaryote evolution (Barakat et al., 2001). Hence, a major current focus of ribosome-related research is to elucidate the adaptive and physiological significance of these divergences and the ribosome heterogeneity that they enable (Wool et al., 1995; Wilson and Doudna Cate, 2012; Xue and Barna, 2012).

\section{PLANT RIBOSOMES - A CHALLENGING TARGET FOR PROTEOMICS}

Plants offer unique technical challenges to researchers of ribosomal proteomes. Firstly, in addition to the cytosolic and mitochondrial ribosomes found in mammals and fungi, plants contain a third type of ribosome in the plastid thus introducing more potential for cross-contamination of ribosome preparations and more potential for ambiguity with respect to the localization of r-proteins when they are detected in multiple cellular fractions. Protocols for the isolation of cytosolic ribosomes from plants must therefore incorporate special measures to avoid contamination from organelle ribosomes.
Another challenge associated with the study of plant ribosomes is that the possible degree of heterogeneity is particularly high (Giavalisco et al., 2005). While mammalian r-proteins are usually represented by only a single expressed gene (Sugihara et al., 2010) and yeast r-proteins are each represented by only one or two, often encoding identical proteins (McIntosh and Warner, 2007), the situation is far more complex in higher plants. Indeed, high heterogeneity appears to be particularly characteristic of higher plants with much less paralog heterogeneity being observed in $80 \mathrm{~S}$ ribosomes of the green alga, Chlamydomonas reinhardtii (Manuell et al., 2005). A survey of the Arabidopsis genome (Barakat et al., 2001) revealed that none of the 80 different r-protein families were encoded by a single-copy gene. Rather, most were found to be encoded by three or four transcribed genes. These paralogs could theoretically combine to form more than $10^{34}$ different ribosomes, not including different post-translational modifications (PTMs; Hummel et al., 2012). This striking potential for heterogeneity is likely attributable to the sessile nature of plants and their greater need to be adaptable under changing environments than animals, who have more capacity to avoid environmental fluctuations.

A major ongoing challenge has been to determine not only which r-protein families but precisely which of the 251 r-protein genes encoded by the A. thaliana genome (Barakat et al., 2001; Chang et al., 2005) are transcribed and translated into proteins that are incorporated into ribosomes. As will be discussed shortly, a collection of proteomic studies (see Table 1) have confirmed the presence of all but one of the 81 predicted r-protein families and, in the case of many families, the presence of multiple distinct paralogous family members in Arabidopsis ribosomes (Chang et al., 2005; Giavalisco et al., 2005; Carroll et al., 2008; Piques et al., 2009; Turkina et al., 2011; Hummel et al., 2012).

Determining precisely which members of r-protein families are incorporated into ribosomes depends on the ability to confidently discriminate between those protein isoforms. In theory, proteotypic peptides - peptides specific to a single gene-product may be generated from trypsin digestion of most r-proteins and confident detection of these may be used as evidence for the presence of their corresponding specific gene products. However, in silico analysis has revealed that 10 r-protein families (S18, S29, S30, L11, L21, L23, L36a, L38, L40, and L41) exhibit no sequence divergence within them while others (S15a, S16, S2, S20, S4, L11, L35a, L39, and L9) include some members predicted to generate proteotypic peptides and others that would not (Carroll et al., 2008). Hence, proteomics alone will be of limited use for assessing the heterogeneity of the ribosomal proteome in these perfectly homologous r-proteins. This is non-trivial given intriguing observations that, in yeast, independent deletion of paralogous genes encoding sequence-identical proteins cause readily distinguishable phenotypes, suggesting that these paralogous genes are functionally non-equivalent despite the fact that the proteins they encode are predicted to have identical amino acid sequences (Komili et al., 2007; McIntosh and Warner, 2007). Promoter analysis using reporter gene constructs expressed under the promoters of different r-protein paralogs, as exemplified in the L16 family (Williams and Sussex, 1995), will continue to be valuable in determining the physiological significance of these different paralogs. 
Table 1 | Proteomic studies of Arabidopsis thaliana ribosomes - an overview.

\begin{tabular}{|c|c|c|c|}
\hline Study & Tissue & Methods & Detected proteins/information provided \\
\hline $\begin{array}{l}\text { Giavalisco } \\
\text { et al. (2005) }\end{array}$ & Leaves & $\begin{array}{l}\text { Differential centrifugation and sucrose gradients, } \\
\text { 2D-E, and MALDI-TOF PMF }\end{array}$ & $\begin{array}{l}\text { Representatives of } 60 \text { r-protein families including } 87 \text { distinct } \\
\text { r-protein identifications based mainly on intact peptide } \\
\text { masses }\end{array}$ \\
\hline $\begin{array}{l}\text { Chang et al. } \\
\text { (2005) }\end{array}$ & Cell suspension & $\begin{array}{l}\text { Detergent extraction, ultracentrifugation and } \\
\text { sucrose gradient followed by 2D-E, MALDI-TOF } \\
\text { PMF, and some LC-MS/MS. Barium hydroxide } \\
\text { treatment of phospho-proteins }\end{array}$ & $\begin{array}{l}\text { Representatives of } 74 \text { r-protein families including } 77 \text { family } \\
\text { member-specific claims based mainly on intact peptide } \\
\text { masses }\end{array}$ \\
\hline $\begin{array}{l}\text { Carroll et al. } \\
\text { (2008) }\end{array}$ & Cell suspension & $\begin{array}{l}\text { Differential centrifugation and double sucrose } \\
\text { cushion purification followed by 1D-SDS-PAGE and } \\
\text { LC-MS/MS. Titanium dioxide phosphopeptide } \\
\text { enrichment. Use of pepsin and chymotrypsin in } \\
\text { addition to trypsin to increase coverage of low MW } \\
\text { r-proteins. Bioinformatic analysis to quantify gene } \\
\text { family member-specific MS/MS evidence }\end{array}$ & $\begin{array}{l}\text { Representatives of } 80 \text { r-protein families including } 87 \text { family } \\
\text { member-specific identifications based on detailed MS/MS } \\
\text { analysis. } 30 \text { residue-specific post-translational modification } \\
\text { sites including Initiator methionine removal, } \mathrm{N} \text {-terminal } \\
\text { acetylation, serine phosphorylation, lysine mono and } \\
\text { tri-methylation, and N-terminal proline dimethylation }\end{array}$ \\
\hline $\begin{array}{l}\text { Piques } \\
\text { et al. (2009) }\end{array}$ & $\begin{array}{l}\text { Leaves sampled at } \\
\text { different times of the } \\
\text { diurnal cycle }\end{array}$ & $\begin{array}{l}\text { Polysome fractions were isolated by detergent } \\
\text { extraction and sucrose gradient fractionation as } \\
\text { described in Kawaguchi et al. (2003). Proteins were } \\
\text { then acetone-precipitated, trypsin digested, and } \\
\text { analyses directly by nano-LC-MS/MS with } \\
\text { data-dependent MS/MS acquisition. Absolute } \\
\text { protein concentrations were estimated using the } \\
\text { emPAI scoring method of Ishihama et al. (2005) }\end{array}$ & $\begin{array}{l}\text { Estimates of absolute (mol\%) concentrations of r-proteins in } \\
\text { different polysome fractions at different times of day and } \\
\text { night. MS/MS evidence provided to support the detection of } \\
\text { representatives from } 71 \text { r-protein families. MS/MS evidence } \\
\text { for proteotypic peptides from } 92 \text { specific r-proteins } \\
\text { collectively across the various polysome samples }\end{array}$ \\
\hline $\begin{array}{l}\text { Turkina } \\
\text { et al. (2011) }\end{array}$ & $\begin{array}{l}\text { Leaves sampled at } \\
\text { day and night }\end{array}$ & $\begin{array}{l}\text { Detergent extraction followed by } \\
\text { ultracentrifugation through sucrose cushion and } \\
\text { then nano-LC-MS/MS for qualitative analysis. Also, } \\
\text { quantitative phosphoproteomic analysis using } \\
\text { differential isotopic labeling of tryptic peptides by } \\
\text { methyl esterification with IMAC enrichment of } \\
\text { phosphopeptides prior to LC-MS/MS. Provide } \\
\text { counts of family member-specific peptides }\end{array}$ & $\begin{array}{l}\text { Representatives from } 72 \text { r-protein families including family } \\
\text { member-specific identifications of } 71 \text { r-proteins based on } \\
\text { MS/MS. New phosphorylation sites on S6, S2 and L29. } \\
\text { Diurnal changes in phosphorylation levels of S6 and L29 }\end{array}$ \\
\hline $\begin{array}{l}\text { Hummel } \\
\text { et al. (2012) }\end{array}$ & $\begin{array}{l}\text { Leaves } \pm \text { sucrose } \\
\text { feeding }\end{array}$ & $\begin{array}{l}\text { Immunopurification of ribosomes from a transgenic } \\
\text { A. thaliana line expressing a His FLAG Tagged form } \\
\text { of RPL18B (Zanetti et al., 2005; Mustroph et al., } \\
\text { 2009). Relative quantitation with simultaneous } \\
\text { identification by label-free LC-MSE analysis }\end{array}$ & $\begin{array}{l}\text { Representatives of } 74 \text { r-protein families including } 166 \text { family } \\
\text { member-specific identifications. Changes in the levels of } \\
\text { RPS3aA, RPS5A, RPL8B, and RACK1 in response to } \\
\text { sucrose feeding were particularly evident }\end{array}$ \\
\hline
\end{tabular}

Brief details about each of the major proteomic studies of $A$. thaliana ribosomes are provided. PMF, Peptide Mass Fingerprinting; 2D-E, Two-dimensional gel electrophoresis; IMAC, Immobilized Metal Affinity Chromatography; LC-MS/MS, Liquid Chromatography - Tandem Mass Spectrometry; MALDI-TOF, Matrix Assisted Laser Desorption Ionization Time-of-Flight Mass Spectrometry.

\section{DEFINING THE ARABIDOPSIS CYTOSOLIC RIBOSOMAL PROTEOME - PROGRESS TO DATE}

Several proteomic studies of Arabidopsis cytosolic ribosomes have been reported in the literature - each employing its own unique combination of methods for purification, gel separation, mass-spectrometric detection and data analysis (summarized in Table 1). In the earliest of these reports, Giavalisco et al. (2005) combined differential centrifugation and sucrose density gradient purification of Arabidopsis leaf ribosomes with 2D-gel electrophoresis and Matrix Assisted Laser Desorption
Ionization Time-of-Flight Mass Spectrometry (MALDI-TOFMS)-based Peptide Mass Fingerprinting (PMF) to identify protein spots corresponding to 87 distinct r-protein gene products representing 60 of the $80 \mathrm{r}$-protein families. The authors highlighted low molecular weights, high pIs and low numbers of tryptic cleavage sites as possible reasons for the non-detection of the other 20 predicted families of r-proteins in their study. A key finding of the study was that at least 21 of the 60 detected r-protein families were represented by two or more distinct r-proteins (distinct AGIs) and that $>45 \%$ of the distinct r-proteins detected were represented 
by $2-13$ separate spots. Indeed, this confirmed earlier predictions by Barakat et al. (2001) of high ribosomal heterogeneity in plants due to the frequent expression of multiple divergent paralogous r-protein genes. However, it also suggested that plant r-proteins exist in a much wider variety of modification states than those of other organisms (Giavalisco et al., 2005).

Shortly after Giavalisco et al. (2005) published their study of Arabidopsis leaf ribosomes, Chang et al. (2005) published an independent proteomic survey of $80 \mathrm{~S}$ ribosomes isolated from heterotrophic Arabidopsis cell suspensions. This study combined detergent-based tissue lysis with differential centrifugation, sucrose gradient purification, 1D- and 2D-gel electrophoresis with MALDI-TOF-MS PMF and in some cases Liquid Chromatography - Electrospray Ionization - Quadrupole - Time-of-Flight Tandem Mass Spectrometry (LC-ESI-Q-TOF-MS/MS). Protein assignments based on $\sim 850$ peptide identifications (mostly based on MALDI-TOF-MS with 172 based on MS/MS) provided evidence for the ribosomal incorporation of 14 previously undetected r-protein families, bringing the total number of detected families to 74 and leaving only six undetected. This study also presented new evidence to support the identification of particular $r$-protein family members by reporting the masses of ions assigned to tryptic peptides predicted to belong to only one specific gene product. On this basis, Chang et al. (2005) provided paralog-specific evidence for 77 r-proteins with the following 25 r-protein families being represented in the cytosolic ribosomal proteome by more than one structurally distinct member: S3a, S6, S7, S10, S12, S14, S15, S15a, S16, S19, S23, S24, Sa, P0, P2, L4, L7, L7a, L8, L10, L10a, L18a, L26, L27, L31.

Even after considerable efforts by Giavalisco et al. (2005) and Chang et al. (2005) to define the Arabidopsis cytosolic ribosomal proteome, clear opportunities to gain further insight remained. In silico analyses suggested that many r-protein families for which gene-specific peptides were predicted to exist had still not been resolved, suggesting that a higher-coverage proteomic analysis based on peptide MS/MS rather than PMF might yield further evidence with which to resolve particular paralogs. Moreover, while limited tissue-type sampling was one possible reason for the nondetection of some r-proteins, in silico analyses also suggested that the six small and basic r-protein families remaining undetected might have been missed by the previous studies because their tryptic peptides were very small and that their detection may have been aided through the use of complementary proteases yielding larger fragments (Carroll et al., 2008).

Prompted by the above observations, Carroll et al. (2008) undertook a systematic analysis of highly pure $80 \mathrm{~S}$ ribosomes isolated from Arabidopsis cell suspensions by combining an optimized ribosome isolation procedure with 1D gel electrophoresis, LC-ESI-Q-TOF-MS/MS analysis of excised gel bands (using three different proteases on low MW bands to capture larger peptides) and a custom data analysis pipeline to provide deep proteome coverage and high-confidence paralog-specific identifications. This analysis, based on 1446 high-quality MS/MS spectra matching to 795 peptide sequences, provided high-confidence evidence for the presence of 79 of the 80 predicted r-protein families in the ribosomes of Arabidopsis, including five previously undetected r-protein families: S29, S30, L29, L36a, and L39.
To date, the only predicted r-protein family yet to be detected in Arabidopsis ribosomes is the extremely basic (predicted pI of $13.4)$ and small $(3.5 \mathrm{kDa}) \mathrm{L} 41$. The four paralogous L41 genes in the A. thaliana genome (At2g40205, At3g08520, At3g11120, and At3g56020) encode identical proteins with the amino acid sequence MRAKWKKKRMRRLKRKRRKMRQRSK. The strong conservation between eukaryotes of genes encoding this putative r-protein suggests that it is most likely a component of Arabidopsis ribosomes. X-ray crystallography has shown that the yeast ortholog of Arabidopsis L41 forms a bridge between the 40S and 605 subunits (Wilson and Doudna Cate, 2012), deep in the ribosome. For this reason, its non-detection so far in Arabidopsis ribosomes seems more likely to be due to technical limitations of the LC and MS detection approaches used rather than its absence in samples. Given that trypsin is not expected to yield useful peptides from L41, its detection in ribosomes is likely to require either targeted top-down LC-MS methods (Odintsova et al., 2003) or xray crystallography. Top-down LC-MS analyses are likely to require special chromatographic conditions as, with a predicted $\mathrm{pI}$ of 13.4, L41 is likely to be highly charged and therefore unlikely to be retained under typical reverse-phase $\mathrm{pH}$ conditions used in nontargeted top-down proteomics. Perhaps synthetic L41 peptides will prove useful as positive controls for method development and validation.

Carroll et al. (2008) provided strong MS/MS evidence to support the identification of 87 specific r-protein paralogs in total, including 32 not previously reported by Chang et al. (2005). These paralog-specific identifications confirmed previous reports of heterogeneity within S10, S12, S14, S15, S19, S24, S3a, S6, S7, Sa, P0, P1, P2, L10, L10a, L18a, L26, L27, L4, L7, L7a, and L8 (Chang et al., 2005) and provided strong evidence for previously unreported heterogeneity within a further 19 families, namely: S11, S2, S21, S25, S27a, S3, P1, L13a, L17, L18, L22, L23a, L28, L32, L35, L36, L37a, L5, and L6. In the case of six families - namely S15a, S16, S23, L19, and L31 - the paralogspecific detection of only a single family member contrasted with reports of Chang et al. (2005) of heterogeneity within those families. While the fact that Carroll et al. (2008) used much higherstringency filters for their paralog-specific identifications should be considered when comparing these datasets, it is possible that these discrepancies were due at least in part to the tendencies of MALDI-TOF-MS and LC-ESI-Q-TOF-MS/MS to preferentially ionize different peptides (Stapels and Barofsky, 2004). Hence, each platform may have preferentially detected paralog-specific peptides from different r-proteins. Other possible contributors to differences in detected r-protein profiles are, of course, differences in tissue types and growth conditions. Given these considerations, the limited range of analytical techniques employed to date and the fact that new r-protein PTMs have only recently been detected (Turkina et al., 2011), it seems likely that the true extent of ribosome heterogeneity is greater than indicated by any individual study or, indeed, all the studies collectively. For the reader's convenience, Table S1 in Supplementary Material aligns and summarizes the r-protein identifications and posttranslational modification detections reported to date across all of the major proteomic analyses of A. thaliana ribosomes (listed in Table 1). 


\section{TYPE II S15a PROTEINS: COMPONENTS OR CONTAMINANTS OF THE ARABIDOPSIS CYTOSOLIC RIBOSOME?}

The Arabidopsis genome encodes for two evolutionarily distinct classes of S15a r-protein, commonly denoted type I and type II (Chang et al., 2005). There is strong evidence that the type II forms obtained functional mitochondrial targeting sequences to become part of the mitochondrial ribosome during the evolution of higher plants (Adams et al., 2002). Indeed, Carroll et al. (2008) detected paralog-specific peptides for both type II S15a proteins (S15aB and $\mathrm{S} 15 \mathrm{aE}$ ) in Arabidopsis mitochondrial ribosome preparations.

The detection of type II S15a sequences in their crude ribosomal pellet led Chang et al. (2005) to hypothesize that type II S15a proteins might be part of the cytosolic ribosome. However, an alternative explanation for this observation lies in the use of four membrane-solubilizing detergents ( $1 \%$ each of Triton X100, Brij 35, Tween-40, and NP-40) - which would have dissolved mitochondrial membranes (Gurtubay et al., 1980) and released mitochondrial ribosomes and other mitochondrial proteins prior to pelleting of ribosomes by ultracentrifugation - in the ribosome extraction buffers of Chang et al. (2005). Hence, although other mitochondrial ribosomal proteins were not detected, the crude ribosome pellet of Chang et al. (2005) in which the type II proteins were detected (they were not reported in the sucrose gradient purified ribosomes) most probably contained at least a considerable portion of the mitochondrial ribosome population of their experimental cells-albeit at inherently low molar \% levels reflecting their low cellular abundance relative to cytosolic ribosomes (Piques et al., 2009). A mitochondrial origin of the type II S15a proteins cannot, therefore, be ruled out on the basis of that analysis. In contrast, Carroll et al. (2008), who used a detergent-free ribosome extraction buffer containing $0.45 \mathrm{M}$ mannitol as osmoticum to prevent osmotic bursting of organelles and subjected their tissue homogenates to $1500 \times g \times 5 \mathrm{~min}, 16,000 \times g \times 15 \mathrm{~min}$, and $30,000 \times g \times 30 \mathrm{~min}$ centrifugation steps to remove nuclei/chloroplasts, mitochondria and large aggregates of poorly defined insoluble materials prior to ultracentrifugation, did not observe a single peptide mapping to type II S15a proteins in their 80S ribosome preparations despite finding strong MS/MS evidence for proteotypic peptides from type I S15a proteins.

Methods are available to resolve $80 \mathrm{~S}$ and $70 \mathrm{~S}$ chloroplast ribosomes (Yamaguchi, 2011). However, given that the 70S and 80S ribosomes of $C$. reinhardtii sedimented closely on sucrose gradients (Yamaguchi et al., 2003) and that mitochondrial ribosomes from higher plants have been observed to sediment anywhere between 70S (Vasconcelos and Bogorad, 1971; Pinel et al., 1986) and 78S (Leaver and Harmey, 1973, 1976; Pring, 1974), the above observations highlight the importance of early fractionation steps, orthogonal to sucrose gradient purification, in obtaining pure cytosolic ribosomes required for confident discrimination of cytosolic and organellar ribosomal proteomes. In this author's view, this technical point is worth highlighting given the potential functional and evolutionary significance of parallel-targeting of r-proteins to multiple ribosomes in eukaryotic cells and the fact that just a few simple protocol modifications could greatly enhance the utility of future studies in addressing this important possibility.

\section{"NON-RIBOSOMAL" RIBOSOME-ASSOCIATED PROTEINS WHAT IS A NON-RIBOSOMAL PROTEIN?}

Each of the major efforts to qualitatively define the Arabidopsis ribosomal proteome has reported the detection of "nonribosomal" proteins in purified ribosomes (Chang et al., 2005; Giavalisco et al., 2005; Carroll et al., 2008; Hummel et al., 2012). However, the reporting of "non-ribosomal" proteins in purified ribosomes begs the question "how do we define ribosomal proteins?" As many new proteins not orthologous to the original set of 79 proteins originally labeled as core r-proteins by Wool et al. (1995) continue to be confidently detected in purified ribosome samples (Hummel et al., 2012), the classic view of ribosomes as a well-defined proteomic entity with a consistent stoichiometry is rapidly giving way to an increasingly fuzzy model of the ribosomal proteome in which a well-defined set core r-proteins (some of which may not always be associated with ribosomes) serve as a docking station for a poorly defined set of ribosome-associated regulatory proteins for which the natures and functions of their ribosome interactions are unclear (Gilbert, 2011; Xue and Barna, 2012). Due to the large number of ribosome-associated proteins that have now been reported and the fact that further experiments will be required to determine which associations represent bonafide interactions as opposed to non-specific binding, an exhaustive list will not be provided here. Rather, the following sections highlight and discuss some examples for which bona-fide functions are either well established or worthy of further investigation based on independent information (which will be explained below).

\section{RACK1 AND elF6}

Of all the ribosome-associated proteins detected so far in $A$. thaliana ribosomes, orthologs of the mammalian Receptor of Activated C Kinase (RACK1) are the most consistently detected. The RACK1A protein encoded by At1g18080 has been reported in all major proteomic surveys of $A$. thaliana ribosomes to date (Chang et al., 2005; Giavalisco et al., 2005; Carroll et al., 2008; Hummel et al., 2012). A second RACK1 ortholog (RACK1B) encoded by Atlg48630 has also been detected in three independent studies (Chang et al., 2005; Carroll et al., 2008; Hummel et al., 2012) but RACK1C (At3g18130), the third of the three known RACK1 genes in the A. thaliana genome has not yet been detected in A. thaliana ribosomes. The close association of RACK1 with mammalian and yeast ribosomes has been known for some time and its role as a key regulatory component of the eukaryotic translation machinery is now well appreciated (Jakob et al., 2004). While RACK1 does not appear to be essential for translation in yeast, its absence decreases the efficiency of translation and steady state levels of numerous proteins (Shor et al., 2003). RACK1 is believed to play a key role in $80 \mathrm{~S}$ ribosome assembly by directing the phosphorylation (by activated C Kinase) and release of eukaryotic Translation Initiation Factor 6 (eIF6) from the 60S subunit, thus allowing assembly of the 80S ribosome (Ceci et al., 2003; Guo et al., 2011).

In A. thaliana, a collection of studies have identified RACK1 as a key integrator and mediator of hormonal control over translation (Chen et al., 2006; Guo and Chen, 2008; Guo et al., 2009a,b, 2011). In particular, evidence suggests that abscisic acid (ABA) may down-regulate translation generally by inhibiting the transcriptional expression of RACK1 and eIF6 mRNAs, 
although the mechanism by which ABA controls the levels of these mRNAs is currently unclear (Guo et al., 2011). Interestingly, the amount of RACK1A (but not RACK1B) associated with ribosomes/polysomes increased significantly in response to sucrose feeding in A. thaliana (Hummel et al., 2012) - a response that is known to involve ABA signaling pathways (Laby et al., 2000). The Arabidopsis genome encodes two homologs of eIF6 - At3g55620 (eIF6A) and At2g39820 (eIF6B). While both proteins have been demonstrated to interact physically with RACK1 (Guo et al., 2011), only the eIF6A protein has been detected in the ribosomes of $A$. thaliana leaf and suspension cells (Carroll et al., 2008; Hummel et al., 2012). This is consistent with mRNA expression patterns which indicate that while eIF6A mRNA is expressed ubiquitously, eIF6B mRNA is mainly expressed in flower buds, stamens, and pollen (Guo et al., 2011). It remains to be seen whether eIF6B is present in the ribosomes of these tissues.

\section{OS PROTEASOME}

The 20S proteasome forms part of the 26S proteasome complex responsible for the proteolysis of many proteins (particularly those carrying poly ubiquitin tails) in eukaryotic cells (Yang et al., 2004). Subunits of the $20 \mathrm{~S}$ proteasome were detected in polysomal bands on sucrose density gradients by Chang et al. (2005) and also in crude ribosomal pellet by Giavalisco et al. (2005) but not in the highly purified ribosome samples of Carroll et al. (2008). Because of the high abundance and similar sedimentation coefficient of the proteasome complex (when associated with other complexes), there has been some uncertainty whether the association of the proteasome with ribosomes was due to a bona-fide in vivo interaction or simply a non-specific interaction between abundant complexes or simple co-sedimentation (Chang et al., 2005). Indeed, the fact that proteasome subunits were not reported in epitopetag purified $A$. thaliana ribosomes in the same manner as RACK1 (Chang, 2006) suggests that if a bona-fide interaction between the proteasome complex and A. thaliana ribosomes exists, it is more labile than the interaction between ribosomes and RACK1. That said, given that the proteasome is thought to play a role in degrading defective ribosomal products (proteins that result from errors in translation or folding) representing some $30 \%$ of newly synthesized proteins, it would seem efficient to have proteasome complexes localized at the point of protein synthesis to prevent the escape of potentially toxic defective proteins into the cytoplasm. Another possible explanation may lie in the major role played by the proteasome in ribosome biogenesis (Stavreva et al., 2006).

\section{FERRITIN}

Only four ribosome-associated proteins were detected in the ribosome preparations of Carroll et al. (2008). Three of these - namely RACK1A, RACK1B, and eIF6 - have been discussed above. The fourth ribosome-associated protein detected was identified as FERRITIN 3 (FER3; At3g56090). The fact that so few ribosomeassociated proteins were detected in these ribosomes and the striking absence of obvious abundant non-specific binding proteins suggests that FER3 was indeed tightly associated with these ribosomes. The FER3 protein has also been detected in small polysome fractions isolated from the leaves of $A$. thaliana plants in the dark (Piques et al., 2009). This is intriguing given that FER3 is a nuclear-encoded chloroplast-targeted protein that, according to the SUBA database (Heazlewood et al., 2007), has been repeatedly detected in chloroplast preparations by mass spectrometry. In humans, ferritin has been demonstrated to regulate folate metabolism by controlling the translation of cytosolic serine hydroxymethyltransferase (cSHMT) via binding to ferritinresponsive internal ribosome entry site (IRES) in the $5^{\prime} \mathrm{UTR}$ of the cSHMT mRNA (Woeller et al., 2007). The H ferritin involved was also shown to interact physically with the mRNA-binding protein CUGBP1 which is known to interact with the $\alpha$ and $\beta$ subunits of eukaryotic translation initiation factor 2 (eIF2; Woeller et al., 2007). Together, the above observations suggest that the existence of similar mechanisms involving FER3 in A. thaliana should be investigated. The link with chloroplasts is particularly intriguing since it is possible to imagine a mechanism whereby FER3 mediates coordination between the translational activity of cytosolic ribosomes and the function of chloroplasts in response to iron-based signals.

\section{POST-TRANSLATIONAL MODIFICATIONS AND THE NEED FOR "TOP-DOWN" APPROACHES}

Eukaryotic ribosomes are well-known to be rich in many kinds of PTMs. The diversity and conservation of PTMs of r-proteins observed across different eukaryote lineages has been reviewed elsewhere (Carroll et al., 2008) and will not be covered again here. Instead, the discussion of PTMs in this review will focus on providing an updated overview of current knowledge concerning PTMs of $A$. thaliana r-proteins. The different types of PTMs detected in A. thaliana cytosolic ribosomes include initiator methionine removal, $\mathrm{N}$-terminal acetylation, serine phosphorylation, lysine mono-, and tri-methylation, and N-terminal proline dimethylation (Chang et al., 2005; Carroll et al., 2008; Turkina et al., 2011). Specific PTM reports are listed in Table 2. Some particularly important issues concerning $A$. thaliana r-protein PTMs are discussed below.

That phosphorylation sites exist on S6 and the acidic stalk $\mathrm{P}$ proteins has been well established for some time, primarily from work in Zea mays (Szick-Miranda and Bailey-Serres, 2001; Williams et al., 2003). The conservation of these modifications in A. thaliana ribosomes has been confirmed more recently (Chang et al., 2005; Carroll et al., 2008; Turkina et al., 2011). However, new phosphorylation sites continue to emerge as new tissues are analyzed and new methods of analysis are employed. For example, Carroll et al. (2008) recently reported a previously undiscovered phosphorylation site on L13(At3g49010). It should be noted that this r-protein is not homologous to the human r-protein L13a which has been shown to act as an mRNA-binding translational suppressor upon being released from human ribosomes by phosphorylation following treatment of cells with interferon- $\gamma$ (Mazumder et al., 2003). Interestingly, phosphorylated L13 was not detected in a recent quantitative phosphoproteomic analysis of $A$. thaliana leaf cytosolic ribosome despite the detection of previously undetected phosphorylation sites at Ser $_{231}$ of S6 and Ser $_{58}$ of L29A (Turkina et al., 2011). Phosphorylation of the human ortholog of L29 has also been detected (Molina et al., 2007; Wang et al., 2008). Together, these observations highlight the likely plasticity of $A$. thaliana L13 and L29A phosphorylation 
Table 2 | Post-translational modifications reported to date in $A$. thaliana ribosomal proteins.

\begin{tabular}{|c|c|c|c|}
\hline Family & Loci & $\begin{array}{l}\text { Post-translational } \\
\text { modifications }\end{array}$ & Reference \\
\hline L10a & At1g08360 (L10aA) & ${ }^{90} \mathrm{~K}_{\mathrm{m} 3}$ & a \\
\hline L10a & At2g27530 (L10aB) & ${ }^{90} \mathrm{~K}_{\mathrm{m} 3}$ & a \\
\hline L10a & $\begin{array}{l}\text { At1g08360 (L10aA), } \\
\text { At2g27530 (L10aB), } \\
\text { At5g22440 (L10aC) }\end{array}$ & - Met, ${ }^{N \text {-term }} \mathrm{S}_{\mathrm{Ac}}$ & a \\
\hline L12 & $\begin{array}{l}\text { At2g37190 (L12A), } \\
\text { At3g53430 (L12B), } \\
\text { At5g60670 (L12C) }\end{array}$ & 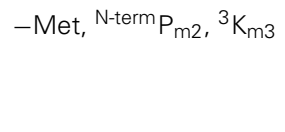 & a \\
\hline L12 & $\begin{array}{l}\text { At2g37190 (L12A), } \\
\text { At3g53430 (L12B), } \\
\text { At5g60670 (L12C) }\end{array}$ & - Met, ${ }^{N \text {-term }} P_{A c}$ & $b$ \\
\hline L13 & At3g49010 (L13B) & ${ }^{137} S_{\text {phospho }}$ & a \\
\hline L15 & At4g16720 (L15A) & ${ }^{N \text {-term }} G_{A c}$ & $b$ \\
\hline L18 & $\begin{array}{l}\text { At3g05590 (L18B), } \\
\text { At5g27850 (L18C) }\end{array}$ & - Met & a \\
\hline L21 & $\begin{array}{l}\text { At1g09590 (L21A), } \\
\text { At1g09690 (L21C), } \\
\text { At1g57660 (L21E), } \\
\text { At1g57860 (L21G) }\end{array}$ & - Met & a \\
\hline L28 & $\begin{array}{l}\text { At2g19730 (L28A), } \\
\text { At4g29410 (L28C) }\end{array}$ & ${ }^{N \text {-term }} A_{A c}$ & $a, b$ \\
\hline L28 & At4g29410 (L28C) & 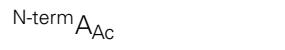 & a \\
\hline L29 & At3g06700 (L29A) & ${ }^{58} S_{\text {phospho }}$ & c \\
\hline L32 & $\begin{array}{l}\text { At4g18100 (L32A), } \\
\text { At5g46430 (L32B) }\end{array}$ & - Met & a \\
\hline L36 & At5g02450 (L36C) & - Met & a \\
\hline L36a & $\begin{array}{l}\text { At3g23390 (L36aA), } \\
\text { At4g14320 (L36aB) }\end{array}$ & ${ }^{55} \mathrm{~K}_{\mathrm{m} 1}$ & a \\
\hline PO & At3g09200 (P0B) & ${ }^{305} S_{\text {phospho }}$ & c \\
\hline PO & At3g11250 (POC) & ${ }^{305} S_{\text {phospho }}$ & a \\
\hline P1 & $\begin{array}{l}\text { At1g01100 (P1A), } \\
\text { At4g00810 (P1B), } \\
\text { At5g47700 (P1C) }\end{array}$ & ${ }^{102 / 103} S_{\text {phospho }}$ & $a, c$ \\
\hline P2 & $\begin{array}{l}\text { At2g27720 (P2A), } \\
\text { At2g27710 (P2B), } \\
\text { At3g44590 (P2D) }\end{array}$ & ${ }^{105} S_{\text {phospho }}$ & a \\
\hline P3 & $\begin{array}{l}\text { At4g25890 (P3A), } \\
\text { At5g57290 (P3B) }\end{array}$ & ${ }^{107} S_{\text {phospho }}$ & a \\
\hline S2 & At2g41840 (S2C) & ${ }^{273} S_{\text {phospho }}$ & c \\
\hline S3 & $\begin{array}{l}\text { At2g31610 (S3A), } \\
\text { At5g35530 (S3C) }\end{array}$ & - Met, ${ }^{N \text {-term }} A_{A c}$ & a \\
\hline S5 & At2g37270 (S5A) &  & $a, b$ \\
\hline S5 & At3g11940 (S5B) & - Met, ${ }^{N \text {-term }} A_{A c}$ & a \\
\hline S6 & At4g31700 (S6A) & ${ }^{240} S_{\text {phospho }}$ & $a, b, c$ \\
\hline S6 & At5g10360 (S6B) & ${ }^{240} S_{\text {phospho }}$ & $a, c$ \\
\hline
\end{tabular}

(Continued)

\begin{tabular}{|c|c|c|c|}
\hline Family & Loci & $\begin{array}{l}\text { Post-translational } \\
\text { modifications }\end{array}$ & Reference \\
\hline S6 & $\begin{array}{l}\text { At4g31700 (S6A), } \\
\text { At5g10360 (S6B) }\end{array}$ & $\begin{array}{l}\text { Mono-, di-, tri-, and } \\
\text { tetra-phospho at } \\
\text { unknown sites in } \mathrm{C} \\
\text { terminal region }\end{array}$ & $b$ \\
\hline S6 & $\begin{array}{l}\text { At4g31700 (S6A), } \\
\text { At5g10360 (S6B) }\end{array}$ & ${ }^{231} S_{\text {phospho }}$ & c \\
\hline S7 & At1g48830 (S7A) & $\mathrm{N}$-term $\mathrm{M}_{\mathrm{Ac}}$ & a \\
\hline S15 & $\begin{array}{l}\text { At1g04270 (S15A), } \\
\text { At5g09510 (S15D) }\end{array}$ & - Met, ${ }^{N-t e r m} A_{A c}$ & $a, b$ \\
\hline S16 & $\begin{array}{l}\text { At2g09990 (S16A), } \\
\text { At5g18380 (S16C) }\end{array}$ & - Met, ${ }^{N-t e r m} A_{A c}$ & $b$ \\
\hline S18 & $\begin{array}{l}\text { At1g22780 (S18A), } \\
\text { At1g34030 (S18B), } \\
\text { At4g09800 (S18C) }\end{array}$ & - Met, ${ }^{N \text {-term }} \mathrm{S}_{\mathrm{Ac}}$ & $a, b$ \\
\hline S20 & $\begin{array}{l}\text { At3g45030 (S20A), } \\
\text { At5g62300 (S20C) }\end{array}$ & -Met, ${ }^{\text {N-term }} A_{A c}$ & a \\
\hline S20 & At3g47370 (S20B) & - Met, ${ }^{N \text {-term }} A_{A c}$ & $a, b$ \\
\hline S21 & At3g53890 (S21B) & $\mathrm{N}$-term $\mathrm{M}_{\mathrm{Ac}}$ & $a, b$ \\
\hline S27 & $\begin{array}{l}\text { At2g45710 (S27A), } \\
\text { At3g61110 (S27B) }\end{array}$ & - Met & a \\
\hline Sa & At1g72370 (SaA) & - Met, ${ }^{N \text {-term }} \mathrm{A}_{A c}$ & a \\
\hline
\end{tabular}

Reports of post-translational modifications of A. thaliana r-proteins are listed in order of r-protein family. Each row corresponds to an individual report of a particular modified peptide. The paralog(s) to which each peptide may be mapped theoretically is indicated in column "Loci" with the listing of several paralogs indicating ambiguity with respect to which paralog carried the indicated modification and the listing of a single paralog indicating that the detected modified peptide was specific to a single paralog. In the column "Post-translational modifications," "-Met" indicates removal of the initiator methionine while other modification(s) reported to be associated with the peptide are indicated in the format residue position $X_{\text {modification type }}$ where $X$ is the one-letter code of the modified amino acid residue. All residue positions are given with the initiator methionine as position 1 regardless of whether this methionine is removed. Abbreviations used include: $\mathrm{N}$-term, $\mathrm{N}$ terminus; Ac, Acetyl; phospho, phosphorylation. Methylation modification types are abbreviated as $m Y$ where $Y$, the number of methyl groups added. In the references column, (a) Carroll et al. (2008), (b) Chang et al. (2005), and (c) Turkina et al. (2011).

and suggest that potential roles of L13 and L29 phosphorylation in translational control need targeted research. The extent to which these and other modifications are conserved across different plant species remains to be seen. However, given the divergence of PTMs seen between the major eukaryote lineages (Carroll et al., 2008), the possibility that the gain or loss of specific r-protein PTM sites by different plant species during plant evolution could have played a role in ecological specialization of plants is too tantalizing not be explored.

Another important point relates to the potential role of posttranslational modification in ribosome heterogeneity. Giavalisco 
et al. (2005) suggested that the observation that $>45 \%$ of specific r-proteins were detected in 2-13 spots was indicative of each being present in various modification states. In contrast, none of the 30 modification sites identified by Carroll et al. (2008) were also detected in an unmodified form. One possible explanation for the greater diversity of modification states observed by Giavalisco et al. (2005) may lay in the higher diversity of cell types expected in leaves compared to relatively homogeneous and undifferentiated cell cultures analyzed by Chang et al. (2005) and Carroll et al. (2008). Another possibility is that the extra spots observed by Giavalisco et al. (2005) were multiply phosphorylated forms that generate multiply phosphorylated peptides that are notoriously difficult to detect directly by mass spectrometry (Choi et al., 2008). Proteolytic degradation, either via natural in vivo mechanisms or during analysis, may have also contributed detection of r-proteins across multiple spots (Finnie and Svensson, 2002; Vohradsky et al., 2008).

The application of "top-down" proteomics techniques involving the direct analysis of intact proteins by LC/MS without protease digestion will be invaluable in resolving the issues discussed above (Zhang and Ge, 2011; Zhou et al., 2011). Top-down approaches complement bottom-up approaches by revealing modification states - such as multiple modifications at distal sites or proteolytic protein truncation - that are masked by protease digestion. Similarly, modifications that are difficult to detect in peptide form (e.g., multiply phosphorylated peptides) may be more amenable to detection in the form of modified whole proteins. Top-down approaches have been used extensively to study the composition and PTMs of mammalian (Louie et al., 1996; Odintsova et al., 2003; Yu et al., 2005) and yeast (Arnold et al., 1999; Lee et al., 2002) ribosomes. However, top-down analyses of plant ribosomes have still to be carried out.

A recent quantitative phosphoproteomic analysis has confirmed that phosphorylation not only contributes to cytosolic ribosome heterogeneity in Arabidopsis, but the relative abundance of different phosphorylated forms of S6 and L29 change during the diurnal cycle (Turkina et al., 2011). The levels of mRNA transcripts encoding the phosphorylated acidic stalk P proteins P1, P2A, P2B, and P3 have been shown to be highly variable across different organs and tissues in Zea mays (Szick-Miranda and Bailey-Serres, 2001). Importantly, while levels of P1, P2A, and P2B (but not P3) proteins in ribosomal extracts were also shown to be variable across different organs and tissues, these levels were poorly correlated with the observed variation in mRNA levels, clearly demonstrating the importance of proteome level studies. This study also demonstrated that the phosphorylation levels of the P1, P2A, and P3 proteins of root tip ribosomes decreased under anoxic conditions.

\section{THE ENZYMES THAT MODIFY ARABIDOPSIS R-PROTEINS ARE LARGELY UNKNOWN}

The identification of enzymes responsible for the post-translation modification of ribosomal proteins has progressed much more slowly in Arabidopsis than in other eukaryotic systems. While the kinase responsible for Arabidopsis S6 phosphorylation has been known for some time (Mizoguchi et al., 1995; Mahfouz et al., 2006), little is known about the enzymes responsible for other modifications of $A$. thaliana r-proteins. In contrast, a variety of $\mathrm{N}$-methyltransferases and acetyltransferases responsible for the modification of r-proteins have been identified in yeast and humans (Arnold et al., 1999; Bachand and Silver, 2004; PorrasYakushi et al., 2005, 2008; Ren et al., 2010; Webb et al., 2010a,b, 2011; Forte et al., 2011). Proteomic analysis of ribosomes isolated from A. thaliana mutants perturbed in orthologous or homologous candidate genes encoding potential ribosome-modifying enzymes will almost certainly be a fruitful line of research.

\section{THE TRANSITION FROM OUALITATIVE TO OUANTITATIVE RIBOSOMAL PROTEOMICS}

With an abundance of qualitative proteomics data suggesting the extreme heterogeneity of cytosolic ribosome populations from whole plant tissues, ribosomal proteomics is now heavily focused on understanding the spatiotemporal distribution and physiological function of this heterogeneity. Ribosome heterogeneity could and probably does occur at many different spatiotemporal scales - from slow developmental changes or constitutive differences in the ribosome populations of distinct organs to rapid changes in minor subcellular populations of ribosomes within single cells. Hence, a major task that will be important for reverseengineering the physiological function of ribosome heterogeneity will be the use of quantitative proteomic approaches to correlate variations in the relative abundances and modification states of different r-protein paralogs across tissues, cell types, subcellularfractions, developmental stages, and environmental and genetic perturbations with ribosome properties and processes upstream and downstream of ribosomes. With this goal in mind, Hummel et al. (2012) and colleagues recently demonstrated, through a highly impressive large-scale label-free $\mathrm{MS}^{\mathrm{E}}$ quantitative proteomic approach, that the paralog composition (particularly in RPS3aA, RPS5A, RPL8B, and RACK1) of A. thaliana leaf cytosolic ribosomes responded significantly to sucrose feeding - a treatment that elicits dramatic changes in gene expression. Similar experiments involving different treatments seem likely to reveal even broader ribosome dynamics involving a wider range of r-proteins.

\section{FROM FORM TO FUNCTION: GENETIC STUDIES OF R-PROTEIN FUNCTION IN ARABIDOPSIS}

While the large-scale use of qualitative and quantitative proteomics approaches to study the composition and dynamics of ribosomes will be essential for elucidating their role in plant physiology, unraveling the precise functions of specific r-proteins will also be greatly assisted by functional genetic studies. A considerable number of genetic studies involving the characterization of $A$. thaliana r-protein mutants have already emerged (see Table 3 for a list of studies, mutants, and phenotypes). Together, these studies highlight, perhaps unsurprisingly, the important role of ribosomes and translation in many aspects of plant development (Byrne, 2009). While the leaf abaxialisation phenotypes of the various r-protein/ASYMMETRIC LEAVES double mutants appear to be somewhat qualitatively independent of which particular r-protein gene is disrupted, the relative severity of different phenotypic subelements does seem to depend to some degree on the identity 
Table 3 | Published $\boldsymbol{A}$. thaliana r-protein mutants and their phenotypes.

\begin{tabular}{|c|c|c|c|c|}
\hline r-Protein (AGI) & Type of mutant & Mutant name & Phenotype & Reference \\
\hline L5A(At3G25520) & $\begin{array}{l}\text { rp/5A/as2 double EMS } \\
\text { mutant }\end{array}$ & ae6-1 as2-101 & $\begin{array}{l}\text { Abaxialised leaves. Increased number of lotus- and } \\
\text { needle-like leaves }\end{array}$ & Yao et al. (2008) \\
\hline L5A(At3G25520) & $\begin{array}{l}\text { rp/5A/as1 double EMS } \\
\text { mutant }\end{array}$ & ae6-1 as $1-101$ & $\begin{array}{l}\text { Abaxialised leaves. Increased number of lotus- and } \\
\text { needle-like leaves }\end{array}$ & Yao et al. (2008) \\
\hline L5A(At3G25520) & rp/5A single EMS mutant & $a e 6-1$ & Normal wildtype phenotype & Yao et al. (2008) \\
\hline L5A(At3g25520) & $\begin{array}{l}\text { rp/5A/as1 double EMS } \\
\text { mutant }\end{array}$ & pgy3 & $\begin{array}{l}\text { Dramatic ectopic lamina outgrowths on the adaxial } \\
\text { side of the leaf }\end{array}$ & Pinon et al. (2008) \\
\hline L5B(At5G39740) & rp/5B single EMS mutant & $r p / 5 b$ & Pale green leaves & Yao et al. (2008) \\
\hline L5B(At5G39740) & $\begin{array}{l}\text { rp/5Bas2-101 double EMS } \\
\text { mutant }\end{array}$ & rp/5b as2-101 & Abaxialised leaves. Almost all leaves needle-like & Yao et al. (2008) \\
\hline L9C(At1g33140) & $\begin{array}{l}\text { rp/9C/as } 1 \text { double EMS } \\
\text { mutant }\end{array}$ & pgy2 & $\begin{array}{l}\text { Dramatic ectopic lamina outgrowths on the adaxial } \\
\text { side of the leaf }\end{array}$ & Pinon et al. (2008) \\
\hline L10A(At1G14320) & $\begin{array}{l}\text { rp/10A homozygous } \\
\text { knockout }\end{array}$ & & Lethal & $\begin{array}{l}\text { Ferreyra et al. } \\
\text { (2010b) }\end{array}$ \\
\hline L10A(At1G14320) & $\begin{array}{l}\text { heterozygous T-DNA } \\
\text { insertion causing reduced } \\
\text { mRNA levels }\end{array}$ & & $\begin{array}{l}\text { Conditional translational deficiency under UV-B } \\
\text { stress }\end{array}$ & $\begin{array}{l}\text { Ferreyra et al. } \\
(2010 b)\end{array}$ \\
\hline L10A(At1g14320) & $\begin{array}{l}\text { rp/10a/ac/5 double EMS } \\
\text { mutant }\end{array}$ & acl5-1 & $\begin{array}{l}\text { Semi-dominant mutation in } \angle 10 A \text { rescues the } \\
\text { severe dwarf phenotype resulting from mutation of } \\
\text { acl5 which encodes thermospermine synthase }\end{array}$ & Imai et al. (2008) \\
\hline L10B(At1G26910) & $\begin{array}{l}\text { heterozygous T-DNA } \\
\text { insertion causing reduced } \\
\text { mRNA levels }\end{array}$ & & $\begin{array}{l}\text { Abnormal growth including reduced size, narrow, } \\
\text { and pointed first leaves, } 77 \% \text { reduction in seedling } \\
\text { leaf size, smaller but similar numbers of leaves } \\
\text { until flowering time at which point the mutant } \\
\text { continued producing leaves and started showing } \\
\text { increased rosette branching. Shorter primary roots } \\
\text { and reduced silique length were also observed }\end{array}$ & $\begin{array}{l}\text { Ferreyra et al. } \\
\text { (2010b) }\end{array}$ \\
\hline L10aB(At2g27530) & $\begin{array}{l}\text { rp/10aB/as1 double EMS } \\
\text { mutant }\end{array}$ & piggyback1 (pgy1) & $\begin{array}{l}\text { Dramatic ectopic lamina outgrowths on the adaxial } \\
\text { side of the leaf }\end{array}$ & Pinon et al. (2008) \\
\hline L23aA(At2G39460) & RNAi knockdown & & $\begin{array}{l}\text { Growth retardation, irregular root and leaf } \\
\text { morphology, abnormal phyllotaxy, and vasculature } \\
\text { and loss of apical dominance }\end{array}$ & $\begin{array}{l}\text { Degenhardt and } \\
\text { Bonham-Smith } \\
\text { (2008) }\end{array}$ \\
\hline L23aB(At3G55280) & RNAi knockdown & & No visible phenotype & $\begin{array}{l}\text { Degenhardt and } \\
\text { Bonham-Smith } \\
\text { (2008) }\end{array}$ \\
\hline L24B(At3G53020) & $\begin{array}{l}\text { rp/24B/as2-101 double } \\
\text { EMS mutant }\end{array}$ & stv1 as2-101 & Abaxialised leaves. Almost all leaves needle-like & Yao et al. (2008) \\
\hline L24B(At3G53020) & EMS mutant & short valve (stv1) & Pale green leaves & Yao et al. (2008) \\
\hline L24B(At3g53020) & EMS mutant & short valve (stv1) & $\begin{array}{l}\text { Basal region of ovary shortened. Gynophore } \\
\text { elongated }\end{array}$ & $\begin{array}{l}\text { Nishimura et al. } \\
(2004,2005)\end{array}$ \\
\hline L27aC(At1g70600) & $\begin{array}{l}\text { rp/27aC/as1 double EMS } \\
\text { mutant }\end{array}$ & $p g y 6 / r p / 27 a c-1 d$ & $\begin{array}{l}\text { Altered shoot development, including leaf } \\
\text { patterning, inflorescence and floral meristem } \\
\text { function, and seed set. A temporal delay in } \\
\text { initiation and outgrowth of cotyledon primordia } \\
\text { leads to development of an enlarged globular } \\
\text { embryo prior to apical domain patterning }\end{array}$ & $\begin{array}{l}\text { Szakonyi and Byrne } \\
\text { (2011) }\end{array}$ \\
\hline
\end{tabular}


Table 3 | Continued

\begin{tabular}{|c|c|c|c|c|}
\hline r-Protein (AGI) & Type of mutant & Mutant name & Phenotype & Reference \\
\hline L27aC(At1g70600) & $\begin{array}{l}\text { rp/27aC knockdown } \\
\text { mutant (T-DNA insertion in } \\
\text { promoter) - homozygous }\end{array}$ & $r p / 27 a c-2$ & Pointed and serrated leaves & $\begin{array}{l}\text { Szakonyi and Byrne } \\
\text { (2011) }\end{array}$ \\
\hline L27aC(At1g70600) & $\begin{array}{l}\text { rp/27aC knockdown } \\
\text { mutant (T-DNA insertion in } \\
\text { promoter) - heterozygous }\end{array}$ & rp/27ac-2/+ & No visible shoot phenotype & $\begin{array}{l}\text { Szakonyi and Byrne } \\
\text { (2011) }\end{array}$ \\
\hline L27aC(At1g70600) & $\begin{array}{l}\text { rp/27aC knockout mutant } \\
\text { (T-DNA insertion in } \\
5^{\prime} \text {-UTR) - homozygous }\end{array}$ & $r p / 27 a c-3$ & $\begin{array}{l}\text { Pointed and serrated leaves (less so than in } \\
\text { rp/27ac-2) }\end{array}$ & $\begin{array}{l}\text { Szakonyi and Byrne } \\
\text { (2011) }\end{array}$ \\
\hline L27aC(At1g70600) & $\begin{array}{l}\text { rpl27aC knockout mutant } \\
\text { (T-DNA insertion in } \\
5^{\prime} \text {-UTR) - heterozygous }\end{array}$ & $r p / 27 a c-3 /+$ & No visible shoot phenotype & $\begin{array}{l}\text { Szakonyi and Byrne } \\
\text { (2011) }\end{array}$ \\
\hline L28A(At2G19730) & $\begin{array}{l}\text { rp/28A/as2 double EMS } \\
\text { mutant }\end{array}$ & ae5-1 as2-101 & $\begin{array}{l}\text { Abaxialised leaves. Increased number of lotus- and } \\
\text { needle-like leaves }\end{array}$ & Yao et al. (2008) \\
\hline L28A(At2G19730) & $\begin{array}{l}\text { rp/28A/as } 1 \text { double EMS } \\
\text { mutant }\end{array}$ & ae5-1 as 1-101 & $\begin{array}{l}\text { Abaxialised leaves. Increased number of lotus- and } \\
\text { needle-like leaves }\end{array}$ & Yao et al. (2008) \\
\hline L28A(At2G19730) & rp/28A single EMS mutant & ae5-1 & $\begin{array}{l}\text { Pale green leaves. First few leaves slightly longer } \\
\text { than wildtype }\end{array}$ & Yao et al. (2008) \\
\hline S5A(At2g37270) & T-DNA insertion knockout & $\begin{array}{l}\text { Arabidopsis } \\
\text { Minute-like } 1 \\
\text { (am/1) }\end{array}$ & $\begin{array}{l}\text { Most cell-division processes delayed or disturbed } \\
\text { in the heterozygous mutant. Development is } \\
\text { completely arrested at an early embryonic stage in } \\
\text { the homozygous mutant }\end{array}$ & Weijers et al. (2001) \\
\hline S6B(At5g10360) & Antisense knockdown & & $\begin{array}{l}\text { Reduced apical dominance and irregular positioning } \\
\text { of leaves and flowers }\end{array}$ & $\begin{array}{l}\text { Morimoto et al. } \\
\text { (2002) }\end{array}$ \\
\hline S10B(At5g41520) & $\begin{array}{l}\text { rps } 10 B-1 / \text { max2-1 double } \\
\text { EMS mutant }\end{array}$ & & $\begin{array}{l}\text { Recessive mutation in } S 10 B \text { suppresses the } \\
\text { excessive branching phenotype of } \max 2-1\end{array}$ & Stirnberg et al. (2012) \\
\hline S13A(At3g60770) & $\begin{array}{l}\text { Transposon-mediated } \\
\text { knockout }\end{array}$ & $\begin{array}{l}\text { Pointed First Leaf } \\
2 \text { (pfl2) }\end{array}$ & $\begin{array}{l}\text { Aberrant leaf and trichome morphology, retarded } \\
\text { root growth, and late flowering. Reproductive } \\
\text { growth otherwise not altered. Reduced number of } \\
\text { palisade cells. No phenotypic changes observed } \\
\text { when crossed with a S18 mutant, pfl1, having a } \\
\text { similar phenotype }\end{array}$ & Ito et al. (2000) \\
\hline S15aE(At4g29430) & $\begin{array}{l}\text { T-DNA insertion } \\
\text { knockdown }\end{array}$ & rps15aE-mut1 & $\begin{array}{l}\text { Greater mean rosette radii and leaf areas and } \\
\text { longer roots }\end{array}$ & $\begin{array}{l}\text { Szick-Miranda et al. } \\
\text { (2010) }\end{array}$ \\
\hline S18A(At1g22780) & T-DNA insertion knockout & $\begin{array}{l}\text { Pointed First Leaf } \\
1 \text { (pfl1) }\end{array}$ & $\begin{array}{l}\text { Pointed first leaves, reduced fresh weight, and } \\
\text { growth retardation }\end{array}$ & $\begin{array}{l}\text { Van Lijsebettens } \\
\text { et al. (1994) }\end{array}$ \\
\hline S27A(At2g45710) & T-DNA insertion knockout & rps27A & $\begin{array}{l}\text { Conditional growth inhibition under genotoxic } \\
\text { stress (growth on } \\
\text { methylmethanesulfonate-containing medium). } \\
\text { Impairment in mRNA degradation after UV } \\
\text { irradiation }\end{array}$ & $\begin{array}{l}\text { Revenkova et al. } \\
\text { (1999) }\end{array}$ \\
\hline
\end{tabular}

EMS, ethylmethanesulfonate; UV, Ultra-violet.

of the disrupted r-protein. These observations support the suggestion that different r-proteins do contribute differently to leaf development (Horiguchi et al., 2011).

In addition to the plethora of developmental defects observed in many r-protein mutants, other interesting phenotypes associated with r-protein mutants include the conditional translational deficiency phenotype of L10A mutants exposed the UV-B stress (Ferreyra et al., 2010a,b) and the conditional growth inhibition of S27A mutants grown on genotoxic methyl methane sulfonatecontaining medium (Revenkova et al., 1999). Also interesting is a defect in mRNA degradation seen in S27A mutants exposed to UV light (Revenkova et al., 1999). 


\section{FUTURE STRATEGIES TO REVERSE-ENGINEER THE PHYSIOLOGICAL ROLE OF RIBOSOME HETEROGENEITY}

One of the fundamental goals of ribosome research is to understand the role of ribosome heterogeneity in translational specialization and control. Indeed, the fact that different mRNA profiles are associated with polysomes isolated from different cell types (Mustroph et al., 2009) or under different environmental conditions (Branco-Price et al., 2005, 2008; Piques et al., 2009; Liu et al., 2012), combined with the fact that ribosome heterogeneity is also under environmental and developmental control (Szick-Miranda and Bailey-Serres, 2001; Branco-Price et al., 2005, 2008; Turkina et al., 2011; Hummel et al., 2012) suggests that there may well be a link. The existence of so many paralogs of each r-protein family in the genome of Arabidopsis means that more than $10^{34}$ theoretical r-protein combinations could potentially be formed invivo (Hummel et al., 2012). Such incredible capacity for ribosome heterogeneity makes the notion of a ribosome "code" - whereby different ribosomes are optimized for or dedicated to the translation of specific mRNAs (Komili et al., 2007) - particularly alluring. However, proving the existence or otherwise of a ribosome code will be extremely challenging.

It will probably never be possible to resolve and characterize every single one of the $10^{34}$ potential ribosomes. However, we may be able to significantly deepen our understanding of the role of changes or differences in ribosome composition in translational specificity by fractionating ribosome and polysome populations, analyzing the fractions by translatomic (Mustroph et al., 2009) and quantitative proteomic (Hummel et al., 2012) approaches and then mining the resulting data for correlations between ribosome composition and translational behavior. The phosphorylation of $\mathrm{S} 6$ has already been correlated with differential mRNA recruitment to ribosomes (Scharf and Nover, 1982; Turck et al., 2004). However, global integrated proteomic and translatomic analyses across a much wider range of ribosome types will be essential if we hope to properly decipher the ribosome code and resolve causations from correlations with a high degree of confidence.

The correlative approach described above depends on building up sufficient covariance between ribosome composition and translatome profiles. This variation could be obtained in a wide variety of ways. The quantitative proteomic analysis of polysomes from different cell types for which translatome data are already available (Mustroph et al., 2009) may be a fruitful place to start. However, other possibilities might include the separation of free cytoplasmic polysomes and polysomes bound to various subcellular membrane structures such as the endoplasmic reticulum, mitochondria and chloroplast surfaces (Suissa and Schatz, 1982; Kaltimbacher et al., 2006; Fu et al., 2012).

\section{REFERENCES}

Adams, K. L., Daley, D. O., Whelan, J., and Palmer, J. D. (2002). Genes for two mitochondrial ribosomal proteins in flowering plants are derived from their chloroplast or cytosolic counterparts. Plant Cell 14, 931-943.

Arnold, R. J., Polevoda, B., Reilly, J. P., and Sherman, F. (1999). The action

Alternatively, complex polysome populations might be fractionated directly by non-denaturing preparative separation techniques such as free-flow electrophoresis which separates protein complexes and even organelles on the basis of surface charge (Wagner, 1989).

More targeted approaches might include the affinity purification of ribosomes translating "bait" mRNAs containing aptamers enabling their selective immunopurification (along with the ribosomes translating them). Quantitative proteomic comparisons of these ribosomes with those pulled down using control mRNAs might help reveal regulatory elements within test mRNAs that promote their recruitment by polysomes while also revealing the types of ribosomes they attract.

Another targeted approach might be to genetically perturb the expression of particular r-proteins and then monitor and crosscorrelate changes in ribosome composition with changes in the translatome. However, given the high potential for pleiotropic effects when disrupting translation machinery, perhaps an appropriate approach would be to employ inducible, possibly cell typespecific, silencing, or over expression of r-proteins so that timecourse profiling of the ribosomal proteome and translatome can be used to distinguish primary (early) and secondary (later) effects of specific r-protein perturbations.

Another potentially powerful approach to understand how changes in ribosome composition are related to changes in translation may be to apply next-generation ribosome footprinting whereby the exact locations of ribosomes on transcripts is determined by deep sequencing the regions of transcripts that are protected by ribosomes (Ingolia et al., 2009; Lee et al., 2012). Combining this technique with polysome fractionation, genetic-, and environmental-perturbation and quantitative proteomics may reveal, on a genome-wide scale and with single-basepair resolution, how ribosome composition is related to mRNA occupancy and, through motif analysis, the affinity of ribosomes for particular mRNA sequence elements.

Clearly, as far as the structures and functions of ribosomes are concerned, there are still many more questions than answers. Despite being discovered so long ago, ribosomes remain one of the most interesting and crucially important targets for basic and applied biological research. However, being the complex natural nano-machines that they are, they do not give up their secrets easily and will no doubt remain the focus of many research careers well into the foreseeable future.

\section{SUPPLEMENTARY MATERIAL}

The Supplementary Material for this article can be found online at http://www.frontiersin.org/Plant_Proteomics/10.3389/ fpls.2013.00032/abstract

Bain, J. D., Switzer, C., Chamberlin, R., and Bennert, S. A. (1992). Ribosome-mediated incorporation of a non-standard amino acid into a peptide through expansion of the genetic code. Nature 356, 537-539.

Barakat, A., Szick-Miranda, K., Chang, I.-F., Guyot, R., Blanc, G., Cooke, R., et al. (2001). The organization of cytoplasmic ribosomal protein genes in the Arabidopsis genome. Plant Physiol. 127, 398-415.

Benner, S. A. (1994). Expanding the genetic lexicon: incorporating non-standard amino acids into proteins by ribosome-based synthesis. Trends Biotechnol. 12, 158-163. 
Branco-Price, C., Kaiser, K. A., Jang, C. J., Larive, C. K., and Bailey-Serres, J. (2008). Selective mRNA translation coordinates energetic and metabolic adjustments to cellular oxygen deprivation and reoxygenation in Arabidopsis thaliana. Plant J. 56, 743-755.

Branco-Price, C., Kawaguchi, R., Ferreira, R. B., and Bailey-Serres, J. (2005). Genome-wide analysis of transcript abundance and translation in Arabidopsis seedlings subjected to oxygen deprivation. Ann. Bot. 96, 647-660.

Byrne, M. E. (2009). A role for the ribosome in development. Trends Plant Sci. 14, 512-519.

Carroll, A. J., Heazlewood, J. L., Ito, J., and Millar, A. H. (2008). Analysis of the Arabidopsis cytosolic ribosome proteome provides detailed insights into its components and their post-translational modification. Mol. Cell. Proteomics 7, 347-369.

Ceci, M., Gaviraghi, C., Gorrini, C., Sala, L. A., Offenhauser, N., Carlo Marchisio, P., et al. (2003). Release of eIF6 (p27BBP) from the 60S subunit allows $80 \mathrm{~S}$ ribosome assembly. Nature 426, 579-584.

Chang, I.-F. (2006). Mass spectrometrybased proteomic analysis of the epitope-tag affinity purified protein complexes in eukaryotes. Proteomics 6, 6158-6166.

Chang, I.-F., Szick-Miranda, K., Pan, S., and Bailey-Serres, J. (2005). Proteomic characterization of evolutionarily conserved and variable proteins of Arabidopsis cytosolic ribosomes. Plant Physiol. 137, 848-862.

Chen, J.-G., Ullah, H., Temple, B., Liang, J., Guo, J., Alonso, J. M., et al. (2006). RACK1 mediates multiple hormone responsiveness and developmental processes in Arabidopsis. J. Exp. Bot. 57, 2697-2708.

Choi, H., Lee, H.-S., and Park, Z.-Y. (2008). Detection of multiphosphorylated peptides in LC-MS/MS analysis under low $\mathrm{pH}$ conditions. Anal. Chem. 80, 3007-3015.

Degenhardt, R. F., and Bonham-Smith, P. C. (2008). Arabidopsis ribosomal proteins RPL23aA and RPL23aB are differentially targeted to the nucleolus and are disparately required for normal development. Plant Physiol. $147,128-142$.

Ferreyra, M. L. F., Biarc, J., Burlingame, A. L., and Casati, P. (2010a). Arabidopsis L10 ribosomal proteins in UV-B responses. Plant Signal. Behav. $5,1222-1225$.
Ferreyra, M. L. F., Pezza, A., Biarc, J., Burlingame, A. L., and Casati, P. (2010b). Plant L10 ribosomal proteins have different roles during development and translation under ultraviolet-B stress. Plant Physiol. 153, 1878-1894.

Finnie, C., and Svensson, B. (2002). Proteolysis during the isoelectric focusing step of two-dimensional gel electrophoresis may be a common problem. Anal. Biochem. 311, 182-186.

Forte, G. M. A., Pool, M. R., and Stirling, C. J. (2011). Nterminal acetylation inhibits protein targeting to the endoplasmic reticulum. PLoS Biol. 9:e1001073. doi:10.1371/journal.pbio.1001073

Fu, S., Fan, J., Blanco, J., GimenezCassina, A., Danial, N. N., Watkins, S. M., et al. (2012). Polysome profiling in liver identifies dynamic regulation of endoplasmic reticulum translatome by obesity and fasting. PLoS Genet. 8:e1002902. doi:10.1371/journal.pgen.1002902

Giavalisco, P., Wilson, D., Kreitler, T., Lehrach, H., Klose, J., Gobom, J., et al. (2005). High heterogeneity within the ribosomal proteins of the Arabidopsis thaliana $80 \mathrm{~S}$ ribosome. Plant Mol. Biol. 57, 577-591.

Gilbert, W. V. (2011). Functional specialization of ribosomes? Trends Biochem. Sci. 36, 127-132.

Guo, J., and Chen, J.-G. (2008). RACK1 genes regulate plant development with unequal genetic redundancy in Arabidopsis. BMC Plant Biol. 8:108. doi:10.1186/1471-2229-8-108

Guo, J., Wang, J., Xi, L., Huang, W.-D., Liang, J., and Chen, J.-G. (2009a). RACK1 is a negative regulator of ABA responses in Arabidopsis. J. Exp. Bot. 60, 3819-3833.

Guo, J., Wang, S., Wang, J., Huang, W.-D., Liang, J., and Chen, J.-G. (2009b). Dissection of the relationship between RACK1 and heterotrimeric G-proteins in Arabidopsis. Plant Cell Physiol. 50, 1681-1694.

Guo, J., Wang, S., Valerius, O., Hall, H., Zeng, Q., Li, J.-F., et al. (2011). Involvement of Arabidopsis RACK1 in protein translation and its regulation by abscisic acid. Plant Physiol. $155,370-383$.

Gurtubay, J. I. G., Goñi, F. M., GómezFernández, J. C., Otamendi, J. J., and MacArulla, J. M. (1980). Triton X100 solubilization of mitochondrial inner and outer membranes. $J$. Bioenerg. Biomembr. 12, 47-70.

Heazlewood, J. L., Verboom, R. E., Tonti-Filippini, J., Small, I., and Millar, A. H. (2007). SUBA: the Arabidopsis subcellular database. Nucleic Acids Res. 35, D213-D218.
Horiguchi, G., Molla-Morales, A., PerezPerez, J. M., Kojima, K., Robles, P., Ponce, M. R., et al. (2011). Differential contributions of ribosomal protein genes to Arabidopsis thaliana leaf development. Plant $J$. 65, 724-736.

Hummel, M., Cordewener, J. H. G., De Groot, J. C. M., Smeekens, S., America, A. H. P., and Hanson, J. (2012). Dynamic protein composition of Arabidopsis thaliana cytosolic ribosomes in response to sucrose feeding as revealed by label free MSE proteomics. Proteomics 12, 1024-1038.

Imai, A., Komura, M., Kawano, E., Kuwashiro, Y., and Takahashi, T. (2008). A semi-dominant mutation in the ribosomal protein L10 gene suppresses the dwarf phenotype of the acl5 mutant in Arabidopsis thaliana. Plant J. 56, 881-890.

Ingolia, N. T., Ghaemmaghami, S., Newman, J. R. S., and Weissman, J. S. (2009). Genome-wide analysis in vivo of translation with nucleotide resolution using ribosome profiling. Science 324, 218-223.

Ishihama, Y., Oda, Y., Tabata, T., Sato, T., Nagasu, T., Rappsilber, J., et al. (2005). Exponentially modified protein abundance index (emPAI) for estimation of absolute protein amount in proteomics by the number of sequenced peptides per protein. Mol. Cell. Proteomics 4 1265-1272.

Ito, T., Kim, G. T., and Shinozaki, K. (2000). Disruption of an Arabidopsis cytoplasmic ribosomal protein S13homologous gene by transposonmediated mutagenesis causes aberrant growth and development. Plant J. 22, 257-264.

Jakob, N., Jayati, S., Joachim, F., and Poul, N. (2004). Regulation of eukaryotic translation by the RACK1 protein: a platform for signalling molecules on the ribosome. $E M B O$ Rep. 5, 1137-1141.

Kaltimbacher, V., Bonnet, C., Lecoeuvre, G., Forster, V., Sahel, J.-A., and Corral-Debrinski, M. (2006). mRNA localization to the mitochondrial surface allows the efficient translocation inside the organelle of a nuclear recoded ATP6 protein. RNA 12, 1408-1417.

Kannan, K., Vázquez-Laslop, N., and Mankin, A. S. (2012). Selective protein synthesis by ribosomes with a drug-obstructed exit tunnel. Cell $151,508-520$.

Kapp, L. D., and Lorsch, J. R. (2004). The molecular mechanics of eukaryotic translation. Annu. Rev. Biochem. 73, 657-704.
Kawaguchi, R., Williams, A. J., Bray, E. A., and Bailey-Serres, J. (2003). Water-deficit-induced translational control in Nicotiana tabacum. Plant Cell Environ. 26, 221-229.

Komili, S., Farny, N. G., Roth, F. P., and Silver, P. A. (2007). Functional specificity among ribosomal proteins regulates gene expression. Cell $131,557-571$

Laby, R. J., Kincaid, M. S., Kim, D., and Gibson, S. I. (2000). The Arabidopsis sugar-insensitive mutants sis 4 and sis5 are defective in abscisic acid synthesis and response. Plant J. 23, 587-596.

Leaver, C. J., and Harmey, M. A. (1973). Plant mitochondrial nucleic acids Biochem. Soc. Symp. 175-193.

Leaver, C. J., and Harmey, M. A. (1976). Higher-plant mitochondrial ribosomes contain a $5 \mathrm{~S}$ ribosomal ribonucleic acid component. Biochem. J. 157, 275-277.

Lee, S., Liu, B., Lee, S., Huang, S.-X., Shen, B., and Qian, S.-B. (2012). Global mapping of translation initiation sites in mammalian cells at single-nucleotide resolution. Proc. Natl. Acad. Sci. U.S.A. 109, E2424E2432.

Lee, S. W., Berger, S. J., Martinovic, S., Pasa-Tolic, L., Anderson, G. A., Shen, Y., et al. (2002). Direct mass spectrometric analysis of intact proteins of the yeast large ribosomal subunit using capillary LC/FTICR. Proc. Natl. Acad. Sci. U.S.A. 99, 5942-5947.

Liu, M.-J., Wu, S.-H., Chen, H.-M., and $\mathrm{Wu}$, S.-H. (2012). Widespread translational control contributes to the regulation of Arabidopsis photomorphogenesis. Mol. Syst. Biol. 8, 566.

Louie, D. F., Resing, K. A., Lewis, T. S., and Ahn, N. G. (1996). Mass spectrometric analysis of $40 \mathrm{~S}$ ribosomal proteins from Rat-1 fibroblasts. $J$. Biol. Chem. 271, 28189-28198.

Mager, W. H., Planta, R. J., Ballesta, J.-P. G., Lee, J. C., Mizuta, K., Suzuki, K., et al. (1997). A new nomenclature for the cytoplasmic ribosomal proteins of Saccharomyces cerevisiae. Nucleic Acids Res. 25, 4872-4875.

Mahfouz, M. M., Kim, S., Delauney, A. J., and Verma, D. P. S. (2006). Arabidopsis TARGET OF RAPAMYCIN interacts with RAPTOR, which regulates the activity of S6 kinase in response to osmotic stress signals. Plant Cell 18, 477-490.

Manuell, A. L., Yamaguchi, K., Haynes, P. A., Milligan, R. A., and Mayfield, S. P. (2005). Composition and structure of the $80 \mathrm{~S}$ ribosome from 
the green alga Chlamydomonas reinhardtii: $80 \mathrm{~S}$ ribosomes are conserved in plants and animals. J. Mol. Biol. 351, 266-279.

Mazumder, B., Sampath, P., Seshadri, V., Maitra, R. K., Dicorleto, P. E., and Fox, P. L. (2003). Regulated release of L13a from the 60S ribosomal subunit as a mechanism of transcriptspecific translational control. Cell $115,187-198$

McIntosh, K. B., and Warner, J. R. (2007). Yeast ribosomes: variety is the spice of life. Cell 131, 450-451.

Mizoguchi, T., Hayashida, N., Yamaguchi-Shinozaki, K., Kamada, H., and Shinozaki, K. (1995). Two genes that encode ribosomalprotein S6 kinase homologs are induced by cold or salinity stress in Arabidopsis thaliana. FEBS Lett. 358, 199-204.

Molina, H., Horn, D. M., Tang, N., Mathivanan, S., and Pandey, A. (2007). Global proteomic profiling of phosphopeptides using electron transfer dissociation tandem mass spectrometry. Proc. Natl. Acad. Sci. U.S.A. 104, 2199-2204.

Morimoto, T., Suzuki, Y., and Yamaguchi, I. (2002). Effects of partial suppression of ribosomal protein $\mathrm{S} 6$ on organ formation in Arabidopsis thaliana. Biosci. Biotechnol. Biochem. 66, 2437-2443.

Mustroph, A., Zanetti, M. E., Jang, C. J., Holtan, H. E., Repetti, P. P., Galbraith, D. W., et al. (2009). Profiling translatomes of discrete cell populations resolves altered cellular priorities during hypoxia in Arabidopsis. Proc. Natl. Acad. Sci. U.S.A. 106, 18843-18848.

Neumann, H. (2012). Rewiring translation - genetic code expansion and its applications. FEBS Lett. 586, 2057-2064.

Neumann, H., Wang, K., Davis, L., Garcia-Alai, M., and Chin, J. W. (2010). Encoding multiple unnatural amino acids via evolution of a quadruplet-decoding ribosome. Nature 464, 441-444.

Nishimura, T., Wada, T., and Okada, K. (2004). A key factor of translation reinitiation, ribosomal protein $\mathrm{L} 24$, is involved in gynoecium development in Arabidopsis. Biochem. Soc. Trans. 32, 611-613.

Nishimura, T., Wada, T., Yamamoto, K. T., and Okada, K. (2005). The Arabidopsis STV1 protein, responsible for translation reinitiation, is required for auxin-mediated gynoecium patterning. Plant Cell 17, 2940-2953.

Odintsova, T. I., Muller, E. C., Ivanov, A. V., Egorov, T. A., Bienert, R.,
Vladimirov, S. N., et al. (2003). Characterization and analysis of posttranslational modifications of the human large cytoplasmic ribosomal subunit proteins by mass spectrometry and Edman sequencing. J. Protein Chem. 22, 249-258.

Piekna-Przybylska, D., Przybylski, P., Baudin-Baillieu, A., Rousset, J.-P., and Fournier, M. J. (2008). Ribosome performance is enhanced by a rich cluster of pseudouridines in the A-site finger region of the large subunit. J. Biol. Chem. 283, 26026-26036.

Pinel, C., Douce, R., and Mache, R. (1986). A study of mitochondrial ribosomes from the higher plant Solanum tuberosum L. Mol. Biol. Rep. 11, 93-97.

Pinon, V., Etchells, J. P., Rossignol, P., Collier, S. A., Arroyo, J. M., Martienssen, R. A., et al. (2008). Three PIGGYBACK genes that specifically influence leaf patterning encode ribosomal proteins. Development 135, 1315-1324.

Piques, M., Schulze, W. X., Hohne, M., Usadel, B., Gibon, Y., Rohwer, J., et al. (2009). Ribosome and transcript copy numbers, polysome occupancy and enzyme dynamics in Arabidopsis. Mol. Syst. Biol. 5, 314.

Porras-Yakushi, T. R., Whitelegge, J. P., and Clarke, S. (2008). A novel SET domain methyltransferase in yeast: Rkm2-dependent trimethylation of ribosomal protein L12ab at the $\mathrm{N}$ terminus. VOLUME 281 (2006) PAGES 35835-35845. J. Biol. Chem. 283, 15512.

Porras-Yakushi, T. R., Whitelegge, J. P., Miranda, T. B., and Clarke, S. (2005). A novel SET domain methyltransferase modifies ribosomal protein Rpl23ab in yeast. J. Biol. Chem. 280, 34590-34598.

Pring, D. R. (1974). Maize mitochondria: purification and characterization of ribosomes and ribosomal ribonucleic acid. Plant Physiol. 53, 677-683.

Rackham, O., and Chin, J. W. (2005). A network of orthogonal ribosome $\mathrm{x}$ mRNA pairs. Nat. Chem. Biol. 1, 159-166.

Rackham, O., and Chin, J. W. (2006). Synthesizing cellular networks from evolved ribosome-mRNA pairs. Biochem. Soc. Trans. 34, 328-329.

Ren, J., Wang, Y., Liang, Y., Zhang, Y., Bao, S., and Xu, Z. (2010). Methylation of ribosomal protein S10 by protein-arginine methyltransferase 5 regulates ribosome biogenesis. J. Biol. Chem. 285, 12695-12705.

Revenkova, E., Masson, J., Koncz, C., Afsar, K., Jakovleva, L., and
Paszkowski, J. (1999). Involvement of Arabidopsis thaliana ribosomal protein S27 in mRNA degradation triggered by genotoxic stress. $E M B O$ J. 18, 490-499.

Santoro, R., Lienemann, P., and Fussenegger, M. (2009). Epigenetic engineering of ribosomal RNA genes enhances protein production. PLoS ONE 4:e6653. doi:10.1371/journal.pone.0006653

Scharf, K. D., and Nover, L. (1982). Heat-shock-induced alterations of ribosomal protein phosphorylation in plant cell cultures. Cell 30, 427-437.

Shor, B., Calaycay, J., Rushbrook, J., and McLeod, M. (2003). Cpc2/RACK1 is a ribosome-associated protein that promotes efficient translation in Schizosaccharomyces pombe. J. Biol. Chem. 278, 49119-49128.

Stapels, M. D., and Barofsky, D. F. (2004). Complementary use of MALDI and ESI for the HPLC-MS/MS analysis of DNAbinding proteins. Anal. Chem. 76, 5423-5430.

Stavreva, D. A., Kawasaki, M., Dundr, M., Koberna, K., Müller, W. G., Tsujimura-Takahashi, T., et al. (2006). Potential roles for ubiquitin and the proteasome during ribosome biogenesis. Mol. Cell. Biol. 26 , 5131-5145.

Stirnberg, P., Liu, J. P., Ward, S., Kendall, S. L., and Leyser, O. (2012). Mutation of the cytosolic ribosomal protein-encoding RPS10B gene affects shoot meristematic function in Arabidopsis. BMC Plant Biol. 12:160. doi:10.1186/1471-2229-12160

Sugihara, Y., Honda, H., Iida, T., Morinaga, T., Hino, S., Okajima T., et al. (2010). Proteomic analysis of rodent ribosomes revealed heterogeneity including ribosomal proteins L10-like, L22-like 1, and L39-like. J. Proteome Res. 9, 1351-1366.

Suissa, M., and Schatz, G. (1982). Import of proteins into mitochondria. Translatable mRNAs for imported mitochondrial proteins are present in free as well as mitochondria-bound cytoplasmic polysomes. J. Biol. Chem. 257, 13048-13055.

Szakonyi, D., and Byrne, M. E. (2011). Ribosomal protein L27a is required for growth and patterning in Arabidopsis thaliana. Plant J. 65 , 269-281.

Szick, K., Springer, M., and BaileySerres, J. (1998). Evolutionary analyses of the $12-\mathrm{kDa}$ acidic ribosomal P-proteins reveal a distinct protein of higher plant ribosomes. Proc. Natl. Acad. Sci. U.S.A. 95, 2378-2383.

Szick-Miranda, K., and Bailey-Serres, J. (2001). Regulated heterogeneity in 12-kDa P-protein phosphorylation and composition of ribosomes in Maize (Zea mays L.). J. Biol. Chem. 276, 10921-10928.

Szick-Miranda, K., Zanial, A., Zanial, A., Abidayo, S., and Slater, K. C. (2010). Analysis of RPS15aE, an isoform of a plant-specific evolutionarily distinct ribosomal protein in Arabidopsis thaliana, reveals its potential role as a growth regulator. Plant Mol. Biol. Rep. 28, 239-252.

Taira, H., Fukushima, M., Hohsaka, T., and Sisido, M. (2005). Fourbase codon-mediated incorporation of nonnatural amino acids into proteins in a eukaryotic cell-free translation system. J. Biosci. Bioeng. 99, 473-476.

Turck, F., Zilbermann, F., Kozma, S. C. Thomas, G., and Nagy, F. (2004). Phytohormones participate in an S6 kinase signal transduction pathway in Arabidopsis. Plant Physiol. 134, 1527-1535.

Turkina, M. V., Klang Årstrand, H., and Vener, A. V. (2011). Differential phosphorylation of ribosomal proteins in Arabidopsis thaliana plants during day and night. PLoS ONE 6:e29307. doi:10.1371/journal.pone. 0029307

Van Lijsebettens, M., Vanderhaeghen, R., De Block, M., Bauw, G., Villarroel, R., and Van Montagu, M. (1994). An S18 ribosomal protein gene copy at the Arabidopsis PFL locus affects plant development by its specific expression in meristems. $E M B O \mathrm{~J}$. $13,3378$.

Vasconcelos, A. C., and Bogorad, L. (1971). Proteins of cytoplasmic, chloroplast, and mitochondrial ribosomes of some plants. Biochim. Biophys. Acta 228, 492-502.

Vohradsky, J., Branny, P., Li, X.-M., and Thompson, C. J. (2008). Effect of protein degradation on spot $\mathrm{Mr}$ distribution in 2-D gels - a case study of proteolysis during development of Streptomyces coelicolor cultures. Proteomics 8, 2371-2375.

Wagner, H. (1989). Free-flow electrophoresis. Nature 341, 669-670.

Wang, B., Malik, R., Nigg, E. A., and KöRner, R. (2008). Evaluation of the low-specificity protease elastase for large-scale phosphoproteome analysis. Anal. Chem. 80, 9526-9533.

Warner, J. R. (1999). The economics of ribosome biosynthesis in yeast. Trends Biochem. Sci. 24, 437-440.

Webb, K. J., Al-Hadid, Q., Zurita-Lopez, C. I., Young, B. D., Lipson, R. S., and 
Clarke, S. G. (2011). The ribosomal $\mathrm{L} 1$ protuberance in yeast is methylated on a lysine residue catalyzed by a seven- $\beta$-strand methyltransferase. J. Biol. Chem. 286, 18405-18413.

Webb, K. J., Lipson, R. S., Al-Hadid, Q., Whitelegge, J. P., and Clarke, S. G. (2010a). Identification of protein N-terminal methyltransferases in yeast and humans. Biochemistry 49, 5225-5235.

Webb, K. J., Zurita-Lopez, C. I., AlHadid, Q., Laganowsky, A., Young, B. D., Lipson, R. S., et al. (2010b). A novel 3-methylhistidine modification of yeast ribosomal protein $\mathrm{Rpl} 3$ is dependent upon the YIL110W methyltransferase. J. Biol. Chem. 285, 37598-37606.

Weijers, D., Franke-Van Dijk, M., Vencken, R. J., Quint, A., Hooykaas, P., and Offringa, R. (2001). An Arabidopsis minute-like phenotype caused by a semi-dominant mutation in a RIBOSOMAL PROTEIN S5 gene. Development 128, 4289-4299.

Williams, A. J., Werner-Fraczek, J., Chang, I.-F., and Bailey-Serres, J. (2003). Regulated phosphorylation of 40 S ribosomal protein S6 in root tips of maize. Plant Physiol. 132, 2086-2097.

Williams, M. E., and Sussex, I. M. (1995). Developmental regulation of ribosomal protein L16 genes in Arabidopsis thaliana. Plant J. 8, 65-76.

Wilson, D. N., and Doudna Cate, J. H. (2012). The structure and function of the eukaryotic ribosome. Cold Spring Harb. Perspect. Biol. 4, pii: a011536.

Woeller, C. F., Fox, J. T., Perry, C., and Stover, P. J. (2007). A ferritin-responsive internal ribosome entry site regulates folate metabolism. J. Biol. Chem. 282, 29927-29935.

Wool, I. G., Chan, Y.-L., and Glück, A. (1995). Structure and evolution of mammalian ribosomal proteins. Biochem. Cell Biol. 73, 933-947.

Xue, S., and Barna, M. (2012). Specialized ribosomes: a new frontier in gene regulation and organismal biology. Nat. Rev. Mol. Cell Biol. 13, 355-369.

Yamaguchi, K. (2011). "Preparation and proteomic analysis of chloroplast ribosomes," in Chloroplast Research in Arabidopsis, ed. R. P. Jarvis (New York: Humana Press), 241-264.

Yamaguchi, K., Beligni, M. V., Prieto, S., Haynes, P. A., Mcdonald, W. H., Yates, J. R., et al. (2003). Proteomic characterization of the Chlamydomonas reinhardtii chloroplast ribosome. J. Biol. Chem. 278, 33774-33785.
Yang, P., Fu, H., Walker, J., Papa, C. M., Smalle, J., Ju, Y.-M., et al. (2004). Purification of the Arabidopsis $26 \mathrm{~S}$ proteasome: biochemical and molecular analyses revealed the presence of multiple isoforms. J. Biol. Chem. 279, 6401-6413.

Yao, Y., Ling, Q., Wang, H., and Huang, H. (2008). Ribosomal proteins promote leaf adaxial identity. Development 135 , 1325-1334.

Yu, Y., Ji, H., Doudna, J. A., and Leary, J. A. (2005). Mass spectrometric analysis of the human $40 \mathrm{~S}$ ribosomal subunit: native and HCV IRESbound complexes. Protein Sci. 14, 1438-1446.

Zanetti, M. E., Chang, I.-F., Gong, F., Galbraith, D. W., and BaileySerres, J. (2005). Immunopurification of polyribosomal complexes of Arabidopsis for global analysis of gene expression. Plant Physiol. 138, 624-635.

Zhang, H., and Ge, Y. (2011). Comprehensive analysis of protein modifications by top-down mass spectrometry. Circ. Cardiovasc. Genet. 4 711.

Zhou, H., Ning, Z. E., Starr, A., AbuFarha, M., and Figeys, D. (2011). Advancements in top-down proteomics. Anal. Chem. 84, 720-734.
Zorca, S. M., and Zorca, C. E. (2011). The legacy of a founding father of modern cell biology: George Emil Palade (19122008). Yale J. Biol. Med. 84, 113-116.

Conflict of Interest Statement: The authors declare that the research was conducted in the absence of any commercial or financial relationships that could be construed as a potential conflict of interest.

Received: 01 November 2012; accepted: 10 February 2013; published online: 01 March 2013.

Citation: Carroll AJ (2013) The Arabidopsis cytosolic ribosomal proteome: from form to function. Front. Plant Sci. 4:32. doi: 10.3389/fpls.2013.00032

This article was submitted to Frontiers in Plant Proteomics, a specialty of Frontiers in Plant Science.

Copyright (C) 2013 Carroll. This is an open-access article distributed under the terms of the Creative Commons Attribution License, which permits use, distribution and reproduction in other forums, provided the original authors and source are credited and subject to any copyright notices concerning any third-party graphics etc. 